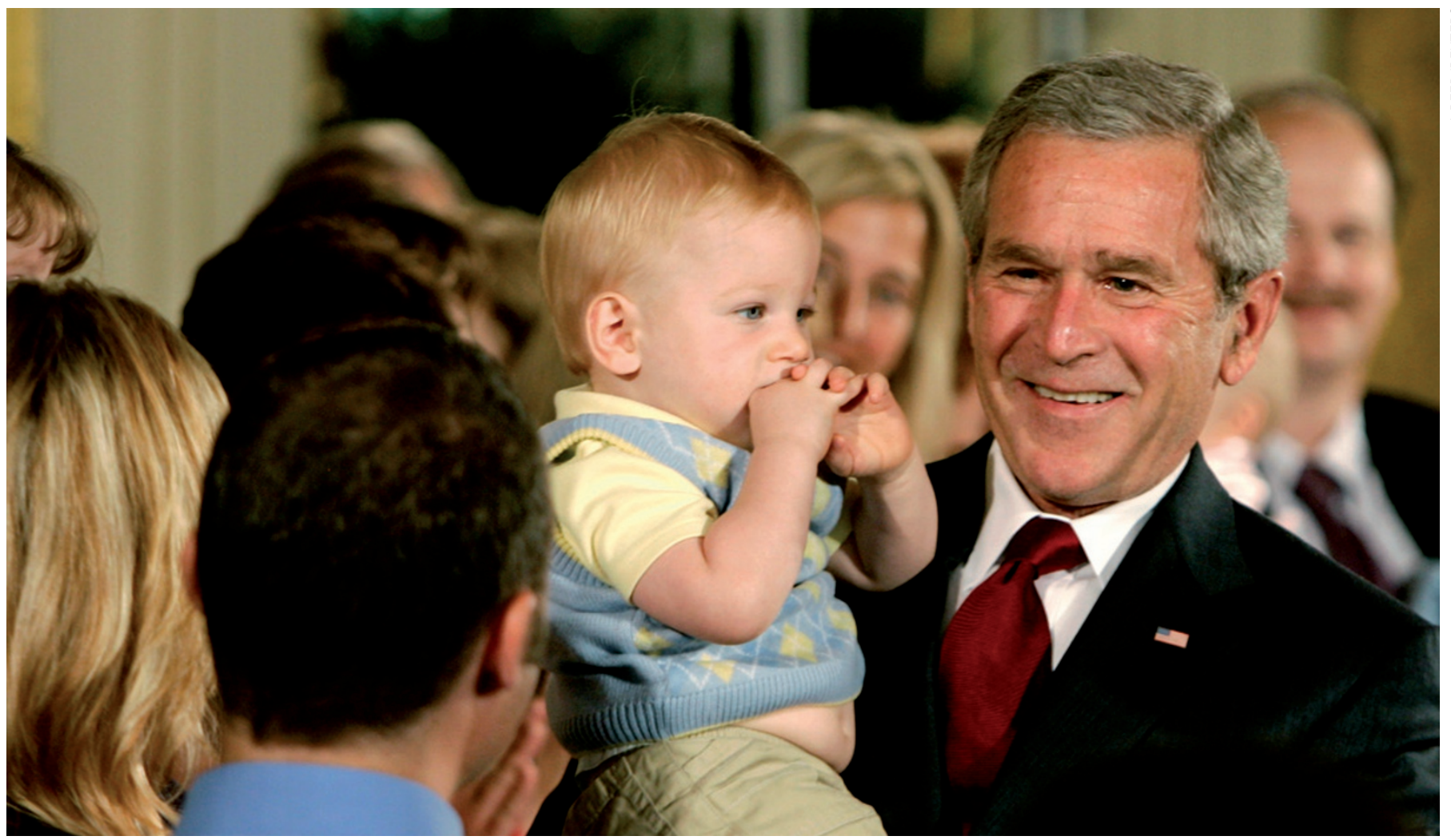

One of the most heated debates in US politics is over the use of human embryonic stem cells. Here, George W. Bush in 2006 holds a child born from a frozen embryo.

\title{
Brave new biopolitics
}

\section{Kevin Finneran hails a timely take on the debate raging over biotechnology breakthroughs in the United States.}

$\mathrm{F}$ rom stem cells to synthetic organisms, advances in the life sciences are as likely to set off a conflagration of debate as a celebration of progress. Such "new biology", says Jonathan Moreno in The Body Politic, challenges our self-perceptions, social values and even political systems. The age of bioscience has become the age of biopolitics.

Moreno, a bioethicist at the University of Pennsylvania in Philadelphia and a fellow at the Center for American Progress in Washington DC, explores this political battlefield in depth. He examines today's wars, and also the historical and philosophical streams that have fed opposing thought about biotechnologies in the United States. His aim is to develop a richer "moral conversation" about bioscience. Moreno devotes much of the book to a critique of what he sees as a neoconservative hostility to science, and explains how science can be a key ingredient of a progressive political agenda.

$\mathrm{He}$ charts the issues well, providing clear summaries of the use in research of pluripotent stem cells derived from human embryos, the implications of the successful cloning of Dolly the sheep and the possible applications of synthetic biology. He covers the use of life-support technology to sustain the lives of patients with severe brain damage; the blurry line between therapeutic and enhancing interventions in human

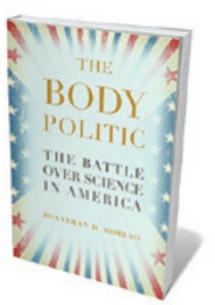

The Body Politic: The Battle

Over Science in America JONATHAN D. MORENO

Bellevue Literary Press: 2011.224 pp. $\$ 18.95$, 12.99 reproduction; and the disconcerting history of eugenics.

Moreno shows how developments in biotechnology have affected people across the ideological spectrum. Over the past decade, these have led to new alliances between political factions and a difficulty in finding common ground between others. The unlikely confraternity that questions the directions taken by life scientists includes conservatives concerned about abortion, neoconservatives worried about threats to human dignity and liberals fretting that new biotechnologies will exacerbate existing economic inequality. In this alliance, people on both the left and right sides of the political divide claim to be motivated by a preference for what is 'natural'. For the right, this usually means conventional human reproduction and the protection of human dignity. For the left, it is species and ecosystems.

Moreno does not engage with arguments from religious conservatives; faith in divine guidance is difficult to refute. His fight is with the neoconservatives, especially those linked with the administration of former US president George W. Bush. Moreno criticizes what he sees as the $\rightarrow$ NATURE.COM Harold Varmus on a guide to US science and government: go.nature.com/adljfa 
neoconservatives' fundamental distrust of human nature, which underlies their belief that people cannot manage technological progress wisely. He makes much of the irony that neoconservatives associate science and technology with human commodification and alienation - the very problems once identified as the hallmarks of capitalism by Karl Marx. Furthermore, he shows that the neoconservative analysis is too shallow: progressives go farther by concluding that the social and economic backdrop to a technology is what determines its impact.

Moreno goes to some lengths to place his ideas in a larger philosophical context that extends from Socrates to Friedrich Nietzsche. In particular, he aims to demonstrate that a progressive, pro-science stance is consistent with the values of the eighteenth-century Enlightenment period that inspired the birth of the United States and the development of other Western democracies.

But Moreno's analysis focuses too heavily on the neoconservatives. He does not address why US Republicans do not object to the use of biotechnology in agriculture or pharmaceuticals, to nuclear power or to new computer and communications technologies. The 'neocon' label in US politics has changed in meaning since it was first coined, and it is now associated mainly with an interventionist foreign policy. Are the main figures from the Bush era - such as Leon Kass, who headed the President's Council on Bioethics from 2001 to 2005 - still influential? How many conservatives would applaud Kass's statement in his book Toward a More Natural Science (Free Press, 1985): "Science - however much it contributes to health, wealth and safety - is neither in spirit nor in manner friendly to the ... moral and civic education of human beings and citizens"?

Moreno frets that the political right wing, by investing in the human factor - such as reproduction - has the advantage in appealing to the public. He encourages the left to build on its concern for human rights and the redistribution of wealth, and to create a progressive biopolitics.

The United States itself provides a model for how allowing scientists to explore and test new ideas can result in benefits for all, says Moreno. The country is an enormous social experiment that evolves by learning from the evidence of what works, and operates through fundamental values such as openness to new ideas. The challenge is to maintain this human side of science when the research, to many people, seems to be a threat to what is essentially human.

Kevin Finneran is editor-in-chief of Issues in Science and Technology, a publication of the US National Academies and the University of Texas at Dallas.

e-mail:kfinnera@nas.edu

\section{Books in brief}

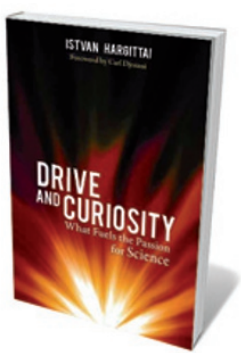

Drive and Curiosity: What Fuels the Passion for Science

Istvan Hargittai PROMETHEUS 338 pp. \$26 (2011)

What propels scientists towards great breakthroughs? Drive and curiosity are only part of it, argues Hungarian chemist Istvan Hargittai. Personality, motivation and accidents of circumstance led luminaries such as the co-discoverer of DNA structure James Watson,

Nobel-prizewinning biochemist Gertrude Elion and theoretical physicist George Gamow to their big discoveries. The snapshot of Frederick Sanger — two-times Nobel prizewinner — is refreshing. The methodical biochemist's regard for doing a steady job, says Hargittai, helped to pave the way to the Human Genome Project.

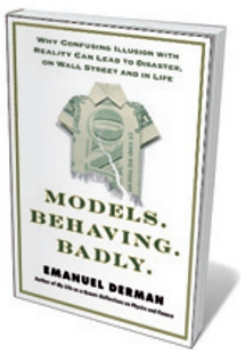

Models. Behaving. Badly: Why Confusing Illusion with Reality Can Lead to Disaster, on Wall Street and in Life

Emanuel Derman FREE PRESS 240 pp. \$26 (2011)

As a theoretical physicist and Wall Street analyst, Emanuel Derman has produced financial models that have become industry standards. But he has long warned that such models, however elegant, are inadequate: human behaviour must be factored in. Derman calls for financial models to be seen as "parallel thought universes" that should be taken with a kilogram of salt. Ranging wittily across philosophy, literature and the arcane world of high finance, Derman's argument is a heady mix of physics, economics and memoir.

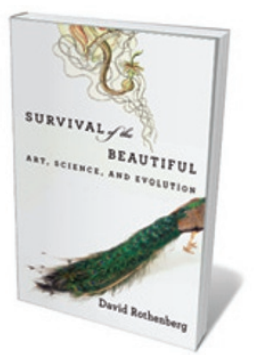

Survival of the Beautiful: Art, Science, and Evolution

David Rothenberg BLOOMSBURY 256 pp. £14.99 (2011)

The colour blue rules for the male satin bowerbird of Australia. The interior decorators of the avian world, they gather plastic, shells and feathers of that hue to adorn their meticulously built stick structures, all to lure a potential mate. This is just one indication, argues philosopher and musician David Rothenberg, that beauty is not random but is intrinsic to life - and that evolution proceeds by sumptuousness, not by utility alone. Rothenberg covers topics such as camouflage, abstraction, the profound impact of art on science and much more to explore his theme.

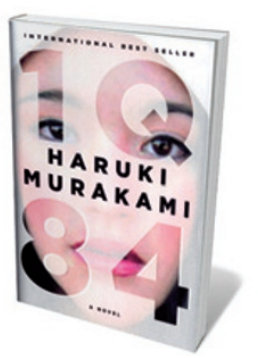

1Q84: Book One and Book Two/1Q84: Book Three

Haruki Murakami HARVILL SECKER 624 pp./368 pp. £20/£14.99 (2011)

This Japanese sci-fi blockbuster, now translated into English by Jay Rubin and Philip Gabriel in two volumes, begins irresistibly. Aomame, a clinically precise assassin, escapes a traffic jam by climbing down an emergency exit - and, like Alice, enters a parallel universe. Meanwhile, mathematics teacher Tengo is rewriting a novel about a two-mooned world ruled by a tribe of 'little people'. Over one year, the lives of Aomame and Tengo slowly converge. Like its near-namesake 1984 , it is a dystopian tale of boy meets girl. It is also a fevered, enigmatic journey into alternative realities and near-past Japan.

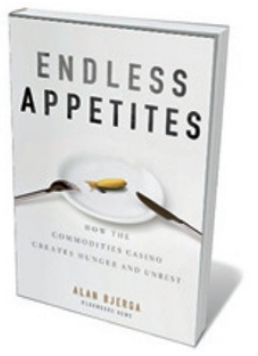

Endless Appetites: How the Commodities Casino Creates Hunger and Unrest

Alan Bjerga JOHN WILEY 208 pp. £18.99 (2011)

Globalization has spawned a crop-market 'casino' in which rich countries gamble over crop prices while millions go hungry. If it can be overcome, says Alan Bjerga, farmers could feed, clothe and fuel the world. Bjerga meshes number-crunching with research gleaned from trading floors in Chicago and farmers in Nicaragua, Thailand and Kenya. Feeding these countries' hardscrabble hectares into the global market is, he concludes, an achievable way to solve hunger. 